Jurnal Ilmu Komunikasi UHO : Jurnal Penelitian Kajian Ilmu Komunikasi dan Informasi.

Volume 7, No. 1, Januari 2022, hlm 1-18

\title{
PENGARUH ELECTRONIC WORD OF MOUTH WOT BATU BANDUNG PADA MEDIA SOSIAL TIKTOK TERHADAP BRAND AWARENESS
}

\author{
Dede Tri Rizky Wijayanti, Berlian Primadani Satria Putri \\ Universitas Telkom, Bandung
}

\begin{abstract}
ABSTRAK
Saat ini TikTok merupakan salah satu media sosial yang digandrungi banyak orang, terbukti dengan aplikasi TikTok saat ini mengalami peningkatan unduhan pada kuartal pertama tahun 2020, dimana saat ini unduhan TikTok di seluruh dunia telah menembus 2 miliar unduhan. Kini TikTok divariasikan dengan berbagai konten lainnya, dengan bantuan hashtag \#fyp. Konten dengan hastag \#fyp ini bisa membuat Electronic Word Of Mouth di TikTok. Penelitian ini dilakukan untuk mengetahui apakah ada pengaruh electronic word of mouth Wot Batu Bandung pada TikTok terhadap brand awareness. Metode yang digunakan dalam penelitian ini adalah kuantitatif, dengan teknik analisis yang digunakan meliputi analisis deskriptif, uji asumsi klasik, analisis regresi linier sederhana, koefisien determinasi, dan pengujian hipotesis. Hasil pengujian hipotesis menggunakan uji-t menunjukkan bahwa electronic word of mouth berpengaruh terhadap brand awareness pada Wot Batu Bandung. Hal ini dibuktikan dengan uji hipotesis uji-t. Dimana nilai thitung lebih besar dari ttabel, karena thitung $(30,882)>$ ttabel $(1,966)$. Sehingga Ha diterima yang artinya ada pengaruh electronic word of mouth terhadap brand awareness Wot Batu Bandung. Dan berdasarkan koefisien determinasi, electronic word of mouth memiliki pengaruh sebesar 70,6\% terhadap brand awareness Wot Batu Bandung.
\end{abstract}

Kata-kata Kunci: Electronic Word Of Mouth, Wot Batu Bandung, TikTok, Brand Awareness 
Jurnal Ilmu Komunikasi UHO : Jurnal Penelitian Kajian Ilmu Komunikasi dan Informasi.

Volume 7, No. 1, Januari 2022, hlm 1-18

\title{
THE EFFECT OF ELECTRONIC WORD OF MOUTH WOT BATU BANDUNG ON TIKTOK SOCIAL MEDIA TOWARD BRAND AWARENESS
}

\begin{abstract}
Today TikTok is one of the social media that is loved by many people, as evidenced by the current TikTok application experiencing an increase in downloads in the first quarter of 2020, where currently TikTok downloads worldwide have penetrated 2 billion downloads. Now TikTok is varied with various other content, with the help of the hashtag \#fyp. This content with the hashtag \#fyp can create Electronic Word Of Mouth on TikTok. This study was conducted to determine whether there is an effect of electronic word of mouth Wot Batu Bandung on TikTok toward brand awareness. The method used in this study is a quantitative, with the analytical techniques used include descriptive analysis, classical assumption test, simple linear regression analysis, coefficient of determination, and hypothesis testing. The results of hypothesis testing using t-test showed that electronic word of mouth had an influence on brand awareness at Wot Batu Bandung. This is evidenced by the t-test hypothesis test. Where the value of tcount is greater than ttable, because tcount $(30,882)>$ ttable $(1,966)$. So that $\mathrm{Ha}$ is accepted, which means that there is an influence of electronic word of mouth on the brand awareness of Wot Batu Bandung. And based on the coefficient of determination, electronic word of mouth has an influence of 70,6\% on Wot Batu Bandung's brand awareness
\end{abstract}

Keywords: Electronic Word Of Mouth, Wot Batu Bandung, TikTok, Brand Awareness 
Jurnal Ilmu Komunikasi UHO : Jurnal Penelitian Kajian Ilmu Komunikasi dan Informasi.

Volume 7, No. 1, Januari 2022, hlm 1-18

\section{PENDAHULUAN}

Di Indonesia media sosial tumbuh sejak tahun 2002, dimulai dengan kehadiran Friendster, LinkedIn, Twitter, Facebook (Raharjo, 2019). Perkembangan media sosial sangat cepat. Hal ini didasarkan bahwa media sosial tidak hanya berfungsi sebagai perantara komunikasi dan sosialisasi saja tetapi media sosial dapat pula dapat dimanfaatkan dengan berbagai kepentingan. (Bimo, 2017). Salah satu kepentingan yang didapatkan dari media sosial adalah kepentingan pemasaran bagi industri produk maupun jasa. Media sosial dimanfaatkan oleh pemasar sebagai alat untuk menciptakan serta meningkatkan brand awareness. Media sosial dipercaya mampu untuk menyampaikan informasi dengan cepat kepada khalayak.

Brand Awareness menurut (Durianto, 2004) adalah sebuah kesanggupan dari seorang potensial customer dalam mengetahui sesuatu baik itu barang atau layanan masuk dalam jenis produk tertentu. Menurut (Rangkuti, 2002:40) brand awareness memiliki tingkatan yang berurutan, diantaranya top of mind, brand recognition, brand recall. Dan dari penjelasan tersebut, dapat disimpulkan bahwasanya penting sebuah produk maupun jasa dikenali dan di ingat oleh konsumen dalam benak mereka. Salah satunya adalah pemanfaatan media sosial sebagai bentuk Electronic Word Of Mouth (E-WOM)

Electronic Word Of Mouth memiliki arti yakni kesediaan secara sukarela dari konsumen untuk merekomendasikan kepada khalayak ke media yang berbasis internet $(\mathrm{Z}$ et al., 2017) dan menurut (Kamtarin, 2012) Electronic Word Of Mouth ini tentunya dijalankan dengan media online seperti e-mail, blog, chat room, juga beberapa media sosial yang memungkinkan konsumen untuk berinterkasi didalamnya. Didalam E-WOM terdapat ungkapan positif yaitu kepuasan konsumen maupun ungkapan negatif yaitu ketidakpuasan dari satu konsumen, calon konsumen, ataupun mantan konsumen mengenai suatu perusahaan kepada banyak orang di internet. (Hennig-Thurau et al., 2004). E-WOM terbagi menjadi 8 dimensi diantaranya, platform assistance, venting negative feelings, concern for other consumers, extraversion/ positive self-enhancement, social benefits, economic incentives, helping the company, advice seeking (Hennig-Thurau et al., 2004)

Adapun dalam penelitian ini, hanya menggunakan enam dimensi variable x yakni platform assistance, concern for other consumers, Extraversion/ positive self-enhancement, Social Benefits, Helping The Company, Advice Seeking. Alasan penulis tidak menggunakan Venting Negative Feelings adalah karena dalam penelitian ini penulis hanya fokus terhadap dimensi Electronic Word Of Mouth yang positif, sedangkan Economic Incentives tidak 
Jurnal Ilmu Komunikasi UHO : Jurnal Penelitian Kajian Ilmu Komunikasi dan Informasi.

Volume 7, No. 1, Januari 2022, hlm 1-18

digunakan karena hasil observasi penulis berupa wawancara dengan beberapa content creator yang menciptakan Electronic Word Of Mouth dengan topik pembahasan Wot Batu Bandung, mereka membuat video konten TikTok Wot Batu Bandung bukan karena alasan untuk mendapatkan insentif dari Wot Batu Bandung, namun karena hanya ingin membagi pengalaman, terutama pengalaman-pengalaman positif mengenai Wot Batu Bandung yang dibuat secara sukarela untuk direkomendasikan kepada pengguna TikTok lainnya.

Dari beberapa penjelasan tersebut, maka E-WOM dapat dijadikan sebagai alat untuk memasarkan produk dan memicu serta meningkatkan brand awareness. Ada banyak media online yang secara jelas terlihat ada E-WOM di dalamnya khususnya media sosial, adanya kolom komentar dan share dalam media sosial memudahkan audience untuk memberikan informasi kepada pengguna lain, salah satunya adalah TikTok. Aplikasi TikTok mengalami peningkatan unduhan dalam periode kuartal pertama tahun 2020 yaitu pengunduhan TikTok diseluruh dunia telah menembus unduhan sebanyak 2 miliar dengan penonton harian mencapai 10 miliar, dan menjadi peringkat pertama unduhan tertinggi baik di App Store maupun Googleplay (www.sensortower.com $)$.

TikTok memiliki berbagai fitur menarik, tidak hanya sebatas fitur like dan komentar, tetapi tiktok juga menyediakan banyak fitur yang memudahkan audience untuk membuat konten dan menciptakan interaksi sesama penggunanya seperti membalas komentar dengan video, Question and Answer, duet, serta sticth. Hal ini memberikan keleluasaan bagi para penggunanya untuk dapat berpendapat melalui berbagai cara. Ada juga penggunaan hashtag saat mengunggah seperti \#fyp, \#dance, \#viral. Hastagh digunakan oleh content creator untuk memudahkan dalam pencarian video dan juga sebagai interaksi bagi sesama pengguna tik tok.

Penjelasan tersebut menjadi alasan penulis memilih TikTok sebagai media sosial yang diteliti, karena kemudahan dalam interaksi dapat memperbesar peluang terjadinya electronic word of mouth sebagaimana yang dijelaskan oleh Kamtarin (2012) yang menyatakan bahwa E-WOM terjadi dalam media online salah satunya media sosial yang memungkinkan konsumen untuk berinteraksi didalamnya. Selain itu, variasi konten yang dimiliki TikTok sangatlah beragam mulai dari berita, berbagi resep makanan, komedi, storytelling, dan salah satunya adalah pemberian rekomendasi atau tanggapan mereka mengenai tempat wisata, belanja, restoran dan sebagainya, hal ini menunjukan bahwa terjadi E-WOM dalam media sosial TikTok sebagaimana yang dikatakan oleh Canhoto \& Kietzmann (2013) yang 
Jurnal Ilmu Komunikasi UHO : Jurnal Penelitian Kajian Ilmu Komunikasi dan Informasi.

Volume 7, No. 1, Januari 2022, hlm 1-18

menyatakan bahwa E-WOM merupakan segala pendapat negatif, netral, dan positif dari pengalaman seorang konsumen terkait barang, tempat, atau jasa.

Salah satu konten TikTok yang berisi rekomendasi tempat wisata yakni konten TikTok dari akun @heyitsme yang dimana konten tersebut memiliki viewers mencapai 336ribu, dengan jumlah likes 42.100, lalu jumlah komentar 561 serta jumlah share ke platform media sosial lain mencapai 1.357. Konten tersebut berupa transisi video yang berisikan rekomendasi mengenai Wot Batu Bandung, terdapat banyak interaksi di kolom komentar yang membentuk Electronic Word Of Mouth.

Jenis electronic word of mouth yang terjadi adalah organic electronic word of mouth yaitu pernyataan tulus atau rekomendasi dari konsumen atau mantan konsumen kepada individu lain mengenai pengalaman positif atau negatifnya menggunakan sebuah produk atau jasa tertentu. Penulis pun melakukan observasi mengenai konten TikTok Wot Batu Bandung melalui kolom pencarian dan hasilnya ditemukan bahwa ada kurang lebih 78 video serupa yang membahas tentang Wot Batu. Selain itu penulis menemukan bahwa jumlah tayangan konten yang menggunakan \#wotbatu telah mencapai 611.700 tayangan berdasarkan pada data dalam kolom pencarian.

Wot Batu merupakan sebuah karya seni pada ruang terbuka yang menampilkan instalasi batu yang berada di Jalan Bukit Pakar Timur, nomor 98, Bandung. Wot Batu ini merupakan sebuah mahakarya dari seniman terkemuka di Indonesia yakni Sunaryo. Wot Batu merupakan proyek terbesar sepanjang karirnya yang mana didalam Wot Batu terdapat 135 batu vulkanik dan 1 batu yang berasal dari Gua Hira yang mengandung narasi makna dan simbol-simbol. Dalam ruangan terbuka yang berukuran $\pm 2000 \mathrm{~m} 2$ batu-batu ditata sedemikian rupa dengan pahatan-pahatan, serta tatahan untuk menciptakan mahakarya yang tak lekang oleh waktu.

Hal tersebut yang menjadi salah satu alasan kenapa penulis memilih Wot Batu sebagai objek penelitian, selain sempat menjadi viral di media sosial TikTok, Wot Batu juga banyak diketahui setelah konten TikTok tersebut viral, hal ini dibuktikan saat penulis mengunjungi Wot Batu dan menanyakan pada salah satu staf disana yaitu Rei yang berperan sebagai tour guide di Wot Batu yang menyatakan terdapat kenaikan jumlah pengunjung semenjak konten mengenai Wot Batu viral di Tiktok.

Bukti ilmiah bahwasanya E-WOM dapat memicu audience untuk mengenali suatu produk adalah penelitian terdahulu dari Severi, E., Choon Ling, K., \& Nasermoadeli, A. yang berjudul "The Impacts of Electronic Word of Mouth on Brand Equity in the Context of 
Jurnal Ilmu Komunikasi UHO : Jurnal Penelitian Kajian Ilmu Komunikasi dan Informasi.

Volume 7, No. 1, Januari 2022, hlm 1-18

Social Media." Yang membuktikan bahwa dalam media sosial dapat tercipta E-WOM dan hal tersebut dapat meningkatkan pengetahuan audience terhadap brand (Severi et al., 2014). Hal tersebut menjadikan penulis melakukan penelitian dengan judul "Pengaruh Elecetronic Word of Mouth Wot Batu Bandung Pada Media Sosial TikTok Terhadap Brand Awareness" Penelitian ini, memiliki topik pembahasan yakni pengaruh dari electronic word of mouth Wot Batu Bandung pada media sosial TikTok terhadap brand awareness dengan identifikasi masalah : "Apakah ada pengaruh electronic word of mouth Wot Batu Bandung pada media sosial TikTok terhadap Brand Awareness" serta "Seberapa besar pengaruh electronic word of mouth Wot Batu Bandung pada media sosial TikTok terhadap Brand Awareness? ”

Berdasarkan identifikasi masalah diatas, penelitian ini memiliki tujuan untuk mengetahui apakah ada pengaruh electronic word of mouth Wot Batu Bandung pada media sosial TikTok terhadap Brand Awareness, dan tentunya juga untuk mengetahui seberapa besar pengaruh electronic word of mouth Wot Batu Bandung pada media sosial TikTok terhadap brand awareness.

\section{METODE PENELITIAN}

Jenis penelitian yang akan digunakan untuk mengetahui seberapa besarnya "Pengaruh Electronic Word Of Mouth Wot Batu Bandung Pada Media Sosial TikTok Terhadap Brand Awareness" adalah dengan menggunakan jenis penelitian kuantitatif. Menurut (Sugiyono, 2013:7) jenis penelitian kuantitatif disebut juga dengan metode tradisional, dikarenakan metode ini telah cukup lama digunakan oleh para peneliti dalam penelitian mereka. Menurut peneliti untuk penelitian ini tepat untuk menggunakan jenis kuantitatif, hal ini karena jenis ini mampu memberikan penjelasan mengenai keterkaitan hubungan diantara kedua variabel, yakni pengaruh electronic word of mouth terhadap brand awareness. Dalam penelitian ini, teknik pengumpulan data yang akan digunakan yakni dengan metode survey yang menggunakan penyebaran kuisioner.

Variabel dalam penlitian ini terdiri dari satu variabel terikat dan satu variabel bebas. menurut Kerlinger dalam Sugiyono (Sugiyono, 2013:39) variabel adalah sifat yang akan dipelajari dari sebuah penelitian. Sedangkan menurut (Sugiyono, 2013:39) variabel penelitian adalah atribut atau karakteristik individu, objek, atau kegiatan, dan bahkan nilai-nilai, yang memiliki perubahan yang secara langsung ditentukan oleh peneliti untuk dipelajari. Variabel bebas merupakan variabel yang dapat memberi pengaruh atau menjadi jawaban timbulnya variabel terikat, variabel bebas dalam penelitian ini Electronic Word Of Moutjh Proses 
Jurnal Ilmu Komunikasi UHO : Jurnal Penelitian Kajian Ilmu Komunikasi dan Informasi.

Volume 7, No. 1, Januari 2022, hlm 1-18

komunikasi dari mulut ke mulut, atau pendapat positif negatif terhadap sebuah barang, brand, atau sebuah perusahaan yang terjadi secara elektronik. Dimensi yang digunakan untuk electronic word of mouth diantaranya Platform Assistance, Concern For Other Consumers, Extraversion/ positive self-enhancement, Social Benefits, Helping The Company, Advice Seeking. Variabel terikat atau variabel dependen merupakan yang dipengaruhi atau dalam sebab akibat variabel ini menjadi akibat dari variabel bebas (Sugiyono, 2013:39). Variabel Terikat dalam penelitian ini adalah Brand Awareness yang merupakan kesanggupan calon pembeli dalam mengingat kembali atau mengenali bahwa suatu brand masuk dalam salah satu kategori produk.. Dimensi yang digunakan untuk brand awareness pada penelitian ini adalah Top of Mind, Brand Recall, Brand Recognition.

Populasi adalah wilayah penelitian yang ditetapkan penulis berdasarkan pada kualifikasi yang harus memenuhi kualitas dan karakteristik yang cocok dalam bentuk objek atau subjek untuk diteliti dan ditarik kesimpulan (Sugiyono, 2013:80). Kali ini, peneliti memiliki kriteria laki-laki dan perempuan pengguna media sosial TikTok di Indonesia tahun 2020 yang berjumlah 30.700 .000 orang, berdasarkan data dari Kementrian Pariwisata dan Ekonomi Kreatif Indonesia pada bulan Juli tahun 2020. Dalam penelitian ini, penulis menggunakan nonprobability sampling yang artinya penulis membatasi populasi untuk tidak memberikan kesamaan peluang pada unsur atau anggota populasi. Menggunakan Sampling Purposive, dimana teknik ini menentukan sampelnya dengan melakukan sebuah pertimbangan. (Sugiyono, 2013: 85), kriteria seseorang yang dijadikan sampel adalah, pengguna TikTok baik laki-laki maupun perempuan yang pernah melihat konten video TikTok mengenai Wot Batu Bandung. Untuk mengetahui responden memenuhi kriteria tersebut atau tidak, peneliti menggunakan pertanyaan saringan pada awal pengisian kuisioner yang berupa pertanyaan "Apakah kamu pernah menonton video TikTok mengenai Wot Batu Bandung?” jika jawaban responden tersebut tidak, maka responden tidak dapat melanjutkan pertanyaan kuisioner. Teknik pengumpulan data dalam penelitian ini menggunakan Kuisioner yang merupakan bentuk pertanyaan yang maengharuskan responden menjawab dengan tujuan untuk mendapatkan tanggapan berupa sikap ataupun reaksi. Pertanyaan yang dipilih dalam kuisioner merupakan pertanyaan yang sebelumnya telah dibangun dan dirasa tepat untuk dijawab oleh responden (Suharsaputra, 2012). Kuisioner dalam penelitian ini akan berupa pertanyaan-pertanyaan terbuka yang akan dibagikan melalui aplikasi google yakni google.docs/form. 
Jurnal Ilmu Komunikasi UHO : Jurnal Penelitian Kajian Ilmu Komunikasi dan Informasi.

Volume 7, No. 1, Januari 2022, hlm 1-18

Dalam penelitian ini penulis melakukan uji validitas, Sugiyono berpendapat bahwa uji validitas adalah untuk mengetahui valid tidaknya hasil penelitian yang dapat dianalisis dari kesamaan antara data yang dikumpulkan oleh penulis dengan data yang sebenarnya terjadi pada objek penelitian. Jika suatu instrumen digunakan untuk mengukur apa yang seharusnya diukur, maka dapat dikatakan valid (Sugiyono, 2019:175). Menurut Tahendrika dalam Natakusumah (2015:57) menjelaskan bahwasanya, kriteria uji validitas adalah Jika $\mathrm{r}$ hitung > $\mathrm{r}$ tabel $=$ instrumen valid dan Jika $\mathrm{r}$ hitung $<\mathrm{r}$ tabel $=$ instrumen tidak valid. Nilai $\mathrm{r}$ tabel untuk $\mathrm{N}=30$ dengan memiliki tingkat signifikannya 5\% $(\mathrm{a}=0,05 \%)$ dan diperoleh angka 0,361 .

Tabel 1 Hasil Uji Validitas Variabel X

\begin{tabular}{ccccc}
\hline Variabel & No. Item & r Hitung & r Tabel & Keterangan \\
Electronic & 1 & 0,654 & 0,361 & Valid \\
Word of & 2 & 0,573 & 0,361 & Valid \\
Mouth & 3 & 0,691 & 0,361 & Valid \\
& 4 & 0,762 & 0,361 & Valid \\
& 5 & 0,667 & 0,361 & Valid \\
& 6 & 0,638 & 0,361 & Valid \\
& 7 & 0,557 & 0,361 & Valid \\
& 8 & 0,753 & 0,361 & Valid \\
& 9 & 0,695 & 0,361 & Valid \\
& 10 & 0,797 & 0,361 & Valid \\
& 11 & 0,642 & 0,361 & Valid \\
& 12 & 0,758 & 0,361 & Valid \\
& 13 & 0,752 & 0,361 & Valid \\
& 14 & 0,707 & 0,361 & Valid \\
& 15 & 0,782 & 0,361 & Valid \\
& 16 & 0,831 & 0,361 & Valid \\
& 17 & 0,646 & 0,361 & Valid \\
\hline
\end{tabular}

Sumber: Olahan Penulis 2021

Tabel 2 Hasil Uji Validitas Variabel Y

\begin{tabular}{ccccc}
\hline Variabel & No.Item & r Hitung & r Tabel & Keterangan \\
Brand & 18 & 0,780 & 0,361 & Valid \\
Awareness & 19 & 0,782 & 0,361 & Valid \\
& 20 & 0,849 & 0.361 & Valid \\
& 21 & 0,663 & 0,361 & Valid \\
& 22 & 0,837 & 0,361 & Valid \\
& 23 & 0,848 & 0,361 & Valid \\
& 24 & 0,529 & 0,361 & Valid \\
& 25 & 0,733 & 0,361 & Valid \\
& 26 & 0,834 & 0,361 & Valid \\
\hline
\end{tabular}

Sumber: Olahan Penulis 2021 
Jurnal Ilmu Komunikasi UHO : Jurnal Penelitian Kajian Ilmu Komunikasi dan Informasi.

Volume 7, No. 1, Januari 2022, hlm 1-18

Hasil Uji validitas untuk variabel $\mathrm{X}$ dan variabel $\mathrm{Y}$ jika dilihat pada tabel 1 dan 2 sudah valid, hal ini dikarenakan $r_{\text {tabel }}$ lebih kecil daripada $r_{\text {hitung. Selanjutnya penulis melakkan }}$ uji reliabilitas yang berfungsi berfungsi sebagai derajat konsistensi sebuah instrumen, yang dimana menjadi realiabel apabila insrumen sudah menjadi alat ukur sebuah objek/ subjek

\section{Tabel 3 Hasil Uji Realibilitas}

\begin{tabular}{ccccc}
\hline No & Variabel & $\begin{array}{c}\text { Cronbach } \\
\text { Alpha's }\end{array}$ & N of Items & Keterangan \\
1 & Electronic Word Of Mouth & 0,935 & 17 & Reliabel \\
2 & Brand Awareness & 0,910 & 9 & Reliabel \\
\hline
\end{tabular}

Sumber: Olahan Penulis 2021

Dari hasil uji realibilitas pada tabel 3.5, peneliti mendapatkan hasil nilai $\alpha 0,931$ untuk variabel $\mathrm{X}$, dan nilai $\alpha$ sebesar 0,881 untuk variabel $\mathrm{Y}$, sehingga kedua variabel tersebut dapat disimpulkan reliabel karena $\alpha>0,6$.

Teknik analisi data dalam penelitian ini menggunakan analisi deksriptif yang merupakan data yang dianalisis dengan cara mendeskripsikan data yang telah dikumpulkan tanpa melalukan generalisasi pada sebuah kesimpulan (Sugiyono, 2019:217). Penelitian ini menggunakan kuisioner yang memiliki berbagai pertanyaan dengan beberapa pilihan jawaban. Dan tanggapan dari responden tersebut akan dimasukkan kedalam kriteria evaluasi untuk setiap pertanyaan.

\section{HASIL DAN PEMBAHASAN}


Jurnal Ilmu Komunikasi UHO : Jurnal Penelitian Kajian Ilmu Komunikasi dan Informasi.

Volume 7, No. 1, Januari 2022, hlm 1-18

Data yang digunakan dalam penelitian ini merupakan data primer yang berasal dari hasil penyebaran kuisioner kepada responden yang merupakan pengguna TikTok di Indonesia yang pernah menonton konten TikToK mengenai Wot Batu Bandung dan berusia sekitar 1424 tahun. Kuisioner yang digunakan penulis dalam penyebarannya menggunakan google form. Total pertanyaan yang diajukan penulis sebanyak 26 pertanyaan ditambah dengan 7 screening question untuk memastikan bahwa responden tersebut masuk kedalam karakteristik penelitian. Hasil yang didapatkan penulis sebanyak 447, dan penulis hanya akan menggunakan 400 data kuisioner untuk penelitian ini. Data yang telah dikumpulkan akan diolah untuk melakukan serangkaian uji yang dilakukan menggunakan aplikasi SPSS 25, uji yang dilakukan adalah uji normalitas, analisis korelasi, uji heteroskedastisitas, uji regresi linear sederhana, uji koefisiensi determinasi, dan uji hipotesis.

Uji normalitas digunakan untuk menentukan data yang digunakan oleh peneliti telah terdistribusi dengan normal atau tidak, sehingga dapat diketahui data tersebut dapat digunakan atau tidak dalam model regresi, Untuk mengetahui data tersebut terdistribusi dengan normal pada uji normalitas Kolmogrov-smirnov korelasi liliefors memiliki beberapa kriteria yaitu Jika probabilitas atau Asyimp.Sig (2-tailed)>0,05 maka Ho diterima dan Jika probabilitas atau Asyimp.Sig (2-tailed) $<0,05$ maka Ho ditolak.

One-Sample Kolmogorov-Smirnov Test

\begin{tabular}{|c|c|c|}
\hline & & $\begin{array}{l}\text { Unstandardiz } \\
\text { ed Residual }\end{array}$ \\
\hline N & & 400 \\
\hline \multirow[t]{2}{*}{ Normal Parameters ${ }^{a, b}$} & Mean & .0000000 \\
\hline & Std. Deviation & 2.68793339 \\
\hline \multirow[t]{3}{*}{ Most Extreme Differences } & Absolute & .042 \\
\hline & Positive & .026 \\
\hline & Negative & -.042 \\
\hline Test Statistic & & .042 \\
\hline Asymp. Sig. (2-tailed) & & $.090^{\mathrm{c}}$ \\
\hline
\end{tabular}

Gambar 1 Uji Normalitas One-Sample Kolmogorov-Smirnov Test

Sumber: Olahan Penulis SPSS 25, 2021 
Jurnal Ilmu Komunikasi UHO : Jurnal Penelitian Kajian Ilmu Komunikasi dan Informasi.

Volume 7, No. 1, Januari 2022, hlm 1-18

Jika dilihat, berdasarkan gambar 1 hasil uji normalitas diketahui 0,90>0,05, sehingga dapat disimpulkan bahwa data telah terdistribusi dengan normal. Setelah dilakukan uji normalitas penulis melakukan uji analisi korelasi yang bertujuan untuk mengetahui hubungan antara electronic word of mouth Wot Batu Bandung dengan brand awareness, peneliti menggunakan analisis korelasi pearson product moment.

\section{Correlations}

\begin{tabular}{|c|c|c|c|}
\hline & & $\mathbf{x}$ & $\mathbf{y}$ \\
\hline \multirow[t]{3}{*}{$\mathbf{x}$} & $\begin{array}{c}\text { Pearson } \\
\text { Correlation }\end{array}$ & 1 & $.840^{* \%}$ \\
\hline & Sig. (2-tailed) & & .000 \\
\hline & $\mathbf{N}$ & 400 & 400 \\
\hline \multirow[t]{3}{*}{$\mathbf{y}$} & $\begin{array}{c}\text { Pearson } \\
\text { Correlation }\end{array}$ & $.840^{* *}$ & 1 \\
\hline & Sig. (2-tailed) & .000 & \\
\hline & $\mathbf{N}$ & 400 & 400 \\
\hline
\end{tabular}

Gambar 2 Tabel Analisis Korelasi

Sumber: Olahan Penulis SPSS 25, 2021

Berdasarkan tabel diatas, dapat diketahui bahwa nilai koefisen korelasi sebesar 0,840. Dan jika dilihat dalam tingkatan korelasinya, korelasi yang terjadi diantara elecetronic word of mouth dan brand awareness termasuk dalam korelasi yang kuat karena termasuk pada interval 0.80-1.000, dan hasil tersebut menunjukkan adanya hubungan antara electronic word of mouth dengan brand awareness. Setelah dilakukan uji analisis korelasi penulis menguji data dengan uji Heterokedastisitas, uji ini dilakukan untuk mengetahui adanya perubahan situasi yang tidak digambarkan seperti model regresi Cara memeriksa gejala heteroskedastisitas adalah dengan melihat pola diagram pencar residual, yakni selisih antara nilai Y prediksi dan nilai Y observasi. Jika, diagaram pencar membentuk pola yang teratur maka regresi mengalami gangguan heteroskedastisitas, dan jika diagram pencar tidak membentuk pola yang teratur maka regresi tersebut tidak mengalami gangguan heteroskedastisitas. 
Jurnal Ilmu Komunikasi UHO : Jurnal Penelitian Kajian Ilmu Komunikasi dan Informasi.

Volume 7, No. 1, Januari 2022, hlm 1-18

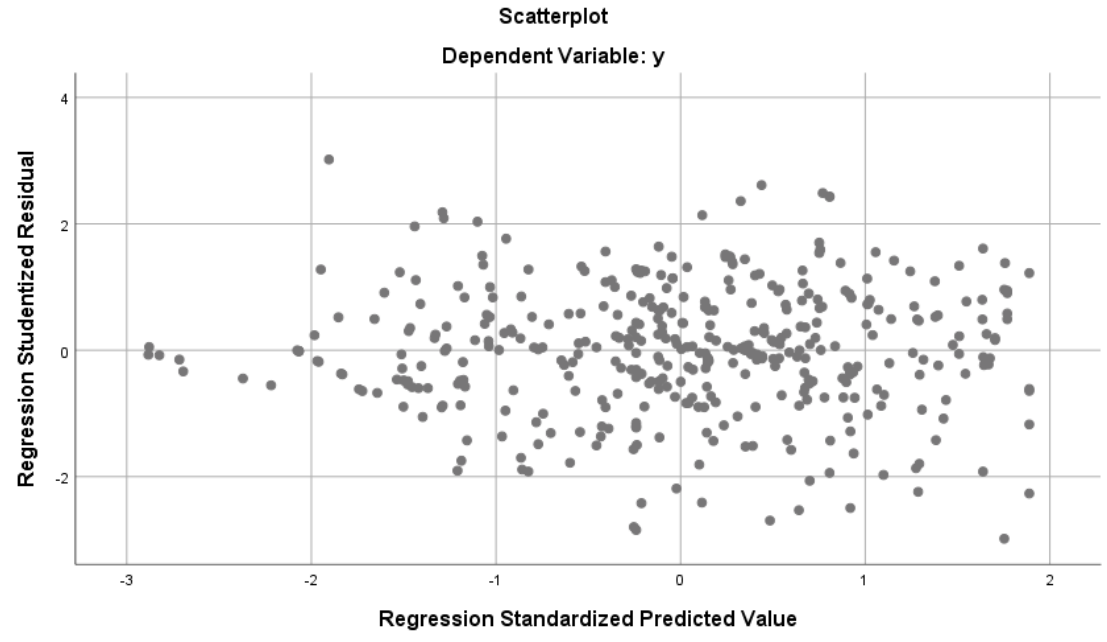

Gambar 3 Diagram Pencar Scatterplot

Sumber: Olahan Penulis SPSS 25, 2021

Dapat dilihat pada Gambar 4.17, diagram pencar tidak membentuk sebuah pola tertentu, maka dapat disimpulkan regresi tidak mengalami gangguan heteroskedastisitas. Uji Regresi Linier Sederhana digunakan untuk mengetahui besarnya pengaruh sebuah variabel bebas (electronic word of mouth) terhadap variabel terikat (brand awareness). Model uji regresi linier sederhana yang digunakan adalah $Y=a+b . X$ Dan berdasarkan hasil pengolahan data menggunakan SPSS 25, maka diperoleh hasil sebagai berikut:

\section{Coefficients $^{\mathrm{a}}$}

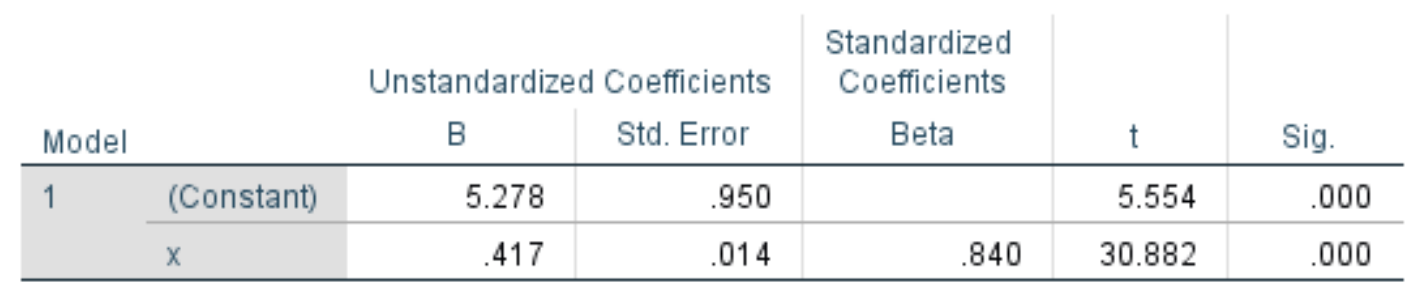

a. Dependent Variable: y

\section{Gambar 5 Uji Regresi Linier Sederhana}

Sumber: Olahan Penulis SPSS 25, 2021

Berdasarkan gambar 5 diatas, maka dapat dirumuskan sebagai berikut $Y=5.278+$ $417 X$. Berdasarkan persamaan tersebut maka dapat diuraikan penjelasan Konstanta $(\alpha)=$ 5.278. Menunjukkan bahwa nilai konstanta yaitu jika variabel electronic word of mouth (X) $=0$, maka brand awareness (Y) tetap sebesar 5.278. Koefisien $(\mathrm{b})=417$. Hal ini menunjukkan bahwa variabel electronic word of mouth $(\mathrm{X})$ berpengaruh secara positif terhadap brand awareness (Y). Artinya jika electronic word of mouth mengalami peningkatan sebesar satu satuan, maka brand awareness pun akan mengalami peningkatan 
Jurnal Ilmu Komunikasi UHO : Jurnal Penelitian Kajian Ilmu Komunikasi dan Informasi.

Volume 7, No. 1, Januari 2022, hlm 1-18

sebesar 417. Dapat disimpulkan bahwasanya electronic word of mouth berpengaruh searah terhadap brand awareness. Selanjutnya untuk mengetahui Pengaruh signifikan antara electronic word of mouth terhadap brand awareness dilakukan uji koefisiensi determinasi dan didapatkan hasil sebagai berikut :

\begin{tabular}{|c|c|c|c|c|}
\hline \multicolumn{5}{|c|}{ Model Summaryb } \\
\hline Model & $\mathrm{R}$ & R Square & $\begin{array}{l}\text { Adjusted R } \\
\text { Square }\end{array}$ & $\begin{array}{c}\text { Std. Error of the } \\
\text { Estimate }\end{array}$ \\
\hline 1 & $.840^{\mathrm{a}}$ & .706 & .705 & 2.69131 \\
\hline
\end{tabular}

\section{Gambar 5 Model Summary}

Sumber: Olahan Penulis SPSS 25, 2021

Pada gambar 5 diatas menunjukkan bahwa nilai $\mathrm{R}$ sebesar 0,840 dan $\mathrm{R}$ square $\left(\mathrm{R}^{2}\right)$ sebesar 0,706. Angka tersebutlah yang digunakan untuk melihat seberapa besar pengaruh dari electronic word of mouth terhadap brand awareness. Dan berikut cara menghitung R square: $K D=r^{2} \times 100 \%=(0,840)^{2} \times 100 \%=70,56 \%$. Angka tersebut menunjukkan koefisien sebesar 70,56\%, dan angka tersebut termasuk dalam kategori sedang. Hal ini menujukkan bahwa pengaruh variabel independen electronic word of mouth terhadap variabel dependen brand awareness sebesar 46,6\%, sedangkan sisanya 29,44\% dipengaruhi oleh faktor lain.

Uji hipotesis Uji hipotesis berfungsi untuk mengetahui pengaruh dari electronic word of mouth sebagai variabel independent (X) terhadap brand awareness sebagai variabel dependent (Y). Dengan hipotesis yang digunakan yakni Hipotesis Nol (Ho) dan Hipotesis Alternatif (Ha) dengan hipotesis yang diajukan dan dibuktikan kebenarannya adalah $\mathrm{H} 0$ : Tidak adanya pengaruh signifikan dari electronic word of mouth terhadap brand awareness dan $\mathrm{Ha}$ : Adanya pengaruh signifikan dari electronic word of mouth terhadap brand awareness. Dengan begitu, kriteria penarikan pengujian jika menggunakan tingkat signifikan $(\alpha=0,05)$, maka kriteria penerimaan atau penolakan sebagai berikut: Apabila $\mathrm{t}$ hitung $>\mathrm{t}$ tabel dan nilai signifikansi kurang dari 0,05, maka Ho ditolak dan Ha diterima. Dan hal tersebut menunjukkan adanya pengaruh signifikan dari variabel bebas terhadap variabel terikat dan Apabila t hitung $<\mathrm{t}$ tabel dan nilai signifikansi lebih dari 0,05, maka Ho diterima dan $\mathrm{Ha}$ ditolak. Hal tersebut menunjukkan tidak adanya pengaruh yang signifikan dari variabel bebas terhadap variabel terikat. 
Jurnal Ilmu Komunikasi UHO : Jurnal Penelitian Kajian Ilmu Komunikasi dan Informasi.

Volume 7, No. 1, Januari 2022, hlm 1-18

\begin{tabular}{|c|c|c|c|c|c|c|}
\hline \multicolumn{7}{|c|}{ Coefficients $^{a}$} \\
\hline & & \multicolumn{2}{|c|}{ Unstandardized Coefficients } & \multirow{2}{*}{$\begin{array}{c}\text { Standardized } \\
\text { Coefficients } \\
\text { Beta }\end{array}$} & \multirow[b]{2}{*}{$t$} & \multirow[b]{2}{*}{ Sig. } \\
\hline Model & & $\mathrm{B}$ & Std. Error & & & \\
\hline \multirow[t]{2}{*}{1} & (Constant) & 5.278 & .950 & & 5.554 & .000 \\
\hline & $x$ & .417 & .014 & .840 & 30.882 & .000 \\
\hline
\end{tabular}

a. Dependent Variable: y

Gambar 6 Uji Hipotesis

Sumber : SPSS 25 Olahan Penulis, 2021

Setelah melakukan perhitungan menggunakan rumus didapatkan nilai $(0.025 ; 398)$, nilai tersebut dalam tabel $\mathrm{t}$ adalah 1,966, beradasrakan perhitungan diatas diketahui bahwa $t_{\text {hitung }}$ sebesar 30,882 , karena $t_{\text {hitung }}(30,882)>t_{\text {tabel }}(1,966)$. Artinya H0 ditolak dan Ha diterima, maka kesimpulannya terdapat pengaruh electronic word of mouth (X) terhadap brand awareness (Y).

Pada penelitian ini menghasilkan bahwasanya electronic word of mouth berpengaruh terhadap brand awareness dari Wot Batu Bandung. Untuk membuktikan adanya pengaruh, penulis melakukan uji hipotesis uji-t. Dalam penelitian ini hipotesis ditemukan bahwasanya $t_{\text {hitung }}$ lebih besar daripada $t_{\text {tabel }}$. Dan asusmsi tersebut dibuktikan dengan H0 mengalami penolakan, sehingga H1 diterima yang artinya yakni, Variabel $\mathrm{X}$ berpengaruh terhadap Variabel Y. Pada uji hipotesis ini menghasilkan $t_{\text {hitung }}$ sebesar 4,950 yang dimana lebih besar dari $\mathrm{t}_{\text {tabel }}$ yang sebesar 1,966.

Selain itu untuk mengetahui hubungan antara Variabel X dan Variabel Y, uji korelasi yang dilakukan oleh penulis mendapatkan hasil koefisien korelasi (r) sebesar 0,840. Hasil tersebut dapat diinterpretasikan kedalam korelasi sempurna atau sangat kuat, menunjukkan bahwa electronic word of mouth memiliki korelasi pada tingkatan sedang terhadap brand awareness. Selanjutnya, untuk mengetahui sejauh mana variabel electronic word of mouth mempengaruhi secara signfikan terhadap variabel brand awareness dibuktikan dengan adanya uji koefisien determinasi. Hasilnya menunjukkan nilai sebesar 70,56\% dan sisanya 29,44\% dipengaruhi oleh faktor lain. Menurut K.Queensberry (2019:44) suara konsumen terhadap suatu brand atau merek dapat meningkatkan brand awareness yang secara langsung akan meningkatkan nilai brand juga loyalitas pelanggan, hal ini dikarenakan konsumen lebih menganggap informasi yang diberikan sesama konsumen adalah sumber yang terpercaya. 
Jurnal Ilmu Komunikasi UHO : Jurnal Penelitian Kajian Ilmu Komunikasi dan Informasi.

Volume 7, No. 1, Januari 2022, hlm 1-18

Hal ini dapat menjelasakan kenapa pengaruh yang dihasilkan electronic word of mouth menyumbang porsi besar dalam brand awareness, selain itu juga menurut Menurut K.Queensberry (2019:44) word of mouth sedari dulu merupakan alat pemasaran terbaik, apalagi dengan adanya media digital memberikan jangkauan yang lebih luas dalam rangka mencapai tujuan perencanaan pemasaran. Selain itu Kotler (2017:41) menyatakan bahwa word of mouth merupakan merupakan salah satu sumber utama atau terbesar untuk menciptakan brand awareness. Sama halnya dengan electronic word of mouth, namun perbedaannya dengan word of mouth terdapat pada media yang digunakan, dengan menggunakan media digital seperti yang dikatakan Queensberry (2019:44) sebelumnya akan memberikan dampak word of mouth yang lebih kuat lagi.

Untuk mengetahui besar pengaruh electronic word of mouth (X) terhadap brand awareness (Y) Wot Batu Bandung, penulis menggunakan uji regresi linier sederhana dan mendapatkan hasil konstanta $(\alpha)=5.278$ menunjukkan bahwa nilai konstanta yaitu jika variabel electronic word of mouth $(\mathrm{X})=0$, maka brand awareness $(\mathrm{Y})$ tetap sebesar 5.278. Koefisien $(b)=417$. Hal ini menunjukkan bahwa variabel electronic word of mouth $(\mathrm{X})$ berpengaruh secara positif terhadap brand awareness (Y). Artinya jika electronic word of mouth mengalami peningkatan sebesar satu satuan, maka brand awareness pun akan mengalami peningkatan sebesar 417 .

\section{SIMPULAN}

Berdasarkan hasil penelitian dan analisis data yang dilakukan oleh penulis, maka dapat ditarik kesimpulan sebagai berikut: Pada penelitian ini terdapat pengaruh yang positif antara variabel electronic word of mouth sebagai variabel $\mathrm{X}$ terhadap brand awareness sebagai variabel Y. Dimana menghasilkan nilai t hitung yang lebih besar daripada t tabel, karena t hitung (30822) \&gt; t tabel $(1,966)$. Sehingga H0 ada dalam daerah penolakan, Ha diterima yang artinya ada pengaruh electronic word of mouth terhadap brand awareness Wot Batu Bandung. Besar pengaruh yang diberikan electronic word of mouth terhadap brand awaraness ditunjukkan oleh besar nilai koefisien determinasi sebesar 70,56\%. Maka dari itu, electronic word of mouth memberikan pengaruh sebesar 70,56\%, dan sisanya dipengaruhi oleh faktor lain.

Dalam penelitian ini terbukti bahwasanya electronic word of mouth berpengaruh terhadap brand awareness. Sehingga dengan begitu membuktikan konten yang dibuat oleh 
Jurnal Ilmu Komunikasi UHO : Jurnal Penelitian Kajian Ilmu Komunikasi dan Informasi.

Volume 7, No. 1, Januari 2022, hlm 1-18

creator dalam media sosial TikTok berdampak terhadap brand awareness suatu merek, maka dari itu hal tersebut dapat menjadi peluang bagi para brand atau perusahaan untuk menjadikan para content creator sebagai sarana untuk memasarkan produk mereka, kesan yang diberikan oleh creator bahwasanya mereka memberikan informasi pada orang lain secara tulus dan ingin berpartisipasi pada komunitas virtual, atau dalam hal ini disebut social benefits dapat meningkatkan kepercayaan konsumen terhadap informasi tersebut benar adanya.

Untuk Wot Batu sendiri diharapkan dapat mengikuti perkembangan dan coba untuk memberikan dorongan lebih terhadap konten-konten mengenai Wot Batu, banyak dari brand atau perusahaan yang membuat official account di Tiktok dan memberikan dukungan bagi para creator yang membuatkan konten mengenai perusahaan tersebut, hal ini selain dapat memberikan apresiasi bagi creator namun juga sekaligus membangun citra perusahaan di ranah public, sebagaiamana yang dikatakan oleh Moriarty et al,. (2017:353) bahwasanya perusahaan yang menggunakan interactive media dapat membangun hubungan antara brand dengan konsumennya.

Penelitian ini diharapkan menjadi pemicu bagi para peneliti lain untuk mengkaji lebih banyak mengenai pengaruh electronic word of mouth ke berbagai variabel lain atau factor lain. Sehingga dapat menghasilkan penelitian yang beragam dan lebih bermanfaat. Contohnya dengan mengkaji Elecronic Word Of Mouth dengan respon khalayak, hal ini dikarenakan ada beberapa dimensi Electrnoic Word Of Mouth yang disampaikan oleh Thurau et al,. (2004) yang memiliki kaitan langsung dengan respon khalyak, seperti social benefits dan advice seeking, yang jika dikaji lebih jauh dapat diketahui apakah social benefits berpengaruh terhadap respon afektif khalayak dan advice seeking terhadap respon kognitif khalayak dan sebagainya. 
Jurnal Ilmu Komunikasi UHO : Jurnal Penelitian Kajian Ilmu Komunikasi dan Informasi.

Volume 7, No. 1, Januari 2022, hlm 1-18

\section{DAFTAR PUSTAKA}

A, Shimp, T. (2003). Periklanan Promosi: Aspek Tambahan Komunikasi Pemasaran Terpadu Jilid 5. Erlangga.

Aaker, D. (1991). Managing Brand Equity. Free Press.

Agustin, N (2021). (PENGARUH ELECTRONIC WORD OF MOUTH DAN IKLAN VIDEO Di INSTGARAM HOUBII URBAN ADVENTURE PARK TERHADAP BRAND AWARENESS)

Anggitasari, A (2016). (PENGARUH eWOM TERHADAP BRAND IMAGE DAN BRAND TRUST, SERTA DAMPAKNYA PADA MINAT BELI PRODUK SMARTPHONE IPHONE)

Canhoto, \& Kietzmann. (2013). Bittersweet! Understanding and Managing Electronic Word of Mouth. Journal of Public Affairs, 15(1), 14-21.

Cheung, C. M. K., \& Thadani, D. R. (2010). The effectiveness of electronic word-of-mouth communication: A literature analysis. 23rd Bled EConference ETrust: Implications for the Individual, Enterprises and Society - Proceedings, February 2009, 329-345.

Durianto, D. (2004). Strategi menaklukan pasar : melalui riset ekuitas dan perilaku merek. Gramedia.

Hasan, A. (2010). Marketing dari Mulut ke Mulut: Word of Mouth Marketing. MedPress.

Hennig-Thurau, T., Gwinner, K. P., Walsh, G., \& Gremler, D. D. (2004). Electronic wordof-mouth via consumer-opinion platforms: What motivates consumers to articulate themselves on the Internet? Journal of Interactive Marketing, 18(1), 38-52.

Jalilvand, M. R., \& Samiei, N. (2012). The effect of electronic word of mouth on brand image and purchase intention: An empirical study in the automobile industry in Iran. Marketing Intelligence and Planning, 30(4), 460-476.

Juni Priansa, D. (2017). Komunikasi Pemasaran Terpadu: Pada Era Media Sosial. Pustaka Setia Bandung.

Kamtarin, M. (2012). The Effect of Electronic Word of Mouth, Trust and Perceived Value on Behavioral Intention from the Perspective of Consumers.

Kaplan, A. M., \& Haenlein, M. (2010). Users of the world, unite! The challenges and opportunities of Social Media. Business Horizons, 53(1), 59-68.

Kasmadi;Sunariah. (2013). Panduan Modern Penelitian Kuantitatif. Alfabeta.

Keller, K. (2012). Management Marketing (14th ed.). Pearson Pentries.

Keller, Kevin L. (2013). Strategic Brand Management ; Building, Measuring, and.Managing Brand Equity. Fourth Edition Harlow, English : Pearson Education. Inc.

Kertajaya, H. (2010). Grow with Character: The Model Marketing. Gramedia.

Kotler, P. (2007). Manajemen Pemasaran Jilid 1.

Kotler, P. (2017). Marketing 4.0. John Wiley \& Sons, Inc., Hoboken.

Kuncoro, E. . \& R. (2013). Cara Menggunakan dan Memakai Path Analysis (Analisis Jalur). Alfabeta.

Moriarty, S., Mitchell, N., Wood, C., \& Wells, W. (2017). Advertising \& IMC; Principles \& Practice. www.pearson.com

Morissan. (2010). Periklanan: Komunikasi Pemasaran Terpadu. Kencana Persada.

Natakusumah, F. . (2015). PENGARUH BAURAN PEMASARAN TERHADAP KEPUTUSAN PEMBELIAN.

Paramitha, C. R. P. (2011). Analisis Faktor Pengaruh Promosi Berbasis Sosial Media Terhadap Keputusan Pembelian Pelanggan dalam Bidang Kuliner. Fakultas Ekonomi 
Jurnal Ilmu Komunikasi UHO : Jurnal Penelitian Kajian Ilmu Komunikasi dan Informasi.

Volume 7, No. 1, Januari 2022, hlm 1-18

Universitas Diponegoro.

Raharjo, F. S. (2019). THE MASTER BOOK OF PERSONAL BRANDING SENI MEMBANGUN MEREK DIRI DENGAN TEKNIK BERBICARA. Anak Hebat Indonesia.

Rangkuti, F. (2002). The power of brands: teknik mengelola brand equity \& strategi pengembangan merk. Gramedia.

Reistian, D. (2019). (PENGARUH ELECTRONIC WORD OF MOUTH TERHADAP RESPON KHALAYAK (Studi Kasus Pada Meme Film Dilan 1990) : THE EFFECT OF ELECTRONIC WORD OF MOUTH MEME OF DILAN 1990 MOVIE TOWARDS AUDIENCE RESPONSE (A Case Study on Meme of Dilan 1990 Movie)).

Sernovitz, A. (2006). Word of Mouth Marketing: How Smart Companies Get People Talking. Kaplan Publishing.

Severi, E., Choon Ling, K., \& Nasermoadeli, A. (2014). The Impacts of Electronic Word of Mouth on Brand Equity in the Context of Social Media. International Journal of Business and Management, 9(8), 84-96.

Shimp, T. A. dan Andrew, C. (2013). Advertising, Promotion, and Other Aspects of Integrated Marketing Communications (9th ed.(. USA: Cengage Learning.

Sugiyono. (2013). Metode Penelitian Kuantitatif, Kualitatif, dan R\&D. Alfabeta.

Sugiyono. (2014). Metode Penelitian Kuantitatif, Kualitatif, dan R\&D. Alfabeta.

Sugiyono. (2018). Metode Penelitian Kuantitatif, Kualitatif, dan R\&D. Alfabeta.

Sugiyono. (2019). Metode Penelitian Kuantitatif, Kualitatif, dan R\&D. Alfabeta.

Surachman. (2008). Dasar-Dasar Manajemen Merek (Alat Pemasaran Untuk Memenangkan Persaingan). BayuMedia Publishing.

Quennsberry, K. A. (2019). Social media strategy: marketing, advertising, and public relations in the consumer revolution. Rowman \& Littlefield Publishers.

Yogeshh K Dwivedi Emmaa Slade Michaell D Williams, E. I. (2017). SPRINGER BRIEFS IN BUSINESS Electronic Word of Mouth (eWOM) in the Marketing Context A State of the Art Analysis and Future Directions.

Z, S., Suharyono, \& Srikandi, K. (2017). PENGARUH KOMUNIKASI ELECTRONICWORD OF MOUTH TERHADAP KEPERCAYAAN (TRUST) DAN NIAT BELI (PURCHASE INTENTION) SERTA DAMPAKNYA PADA KEPUTUSAN PEMBELIAN. 8(2), 97-118.

Bimo, (2017). Perkembangan Media Sosial di Indonesia

https://pakarkomunikasi.com/perkembangan-media-sosial-di-indonesia

Kemp,S. (2021). DIGITAL 2021: INDONESIA

https://datareportal.com/reports/digital-2021-indonesia

Rakhmayanti, (2020). Pengguna TikTok di Indonesia Didominasi Generasi $Z$ dan $Y$ https://tekno.sindonews.com/berita/1523692/207/pengguna-tiktok-di-indonesia-didominasi-

generasi-z-dan-y

http://v1.wotbatu.id/

www.sensortower.com

https://www.instagram.com/wotbatu/ 